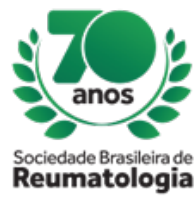

\title{
RHEUMATIC DISEASES: AN EXPERIENCE REPORT WITH A GROUP OF ELDERLY PEOPLE ABOUT THE DISCUSSION AND PREVENTION IN AN INTERACTIVE AND DYNAMIC WAY.
}

Isabelle Louise da Cruz Lopo de Figueiredo (Universidade Federal do Amazonas, Manaus, AM, Brasil), Ronaldo Almeida Lidório Jr (Universidade Federal do Amazonas, Manaus, AM, Brasil), Rodrigo Duarte Machado (Universidade Federal do Amazonas, Manaus, AM, Brasil), Raissa Pires de Medeiros (Universidade Federal do Amazonas, Manaus, AM, Brasil), Gabriel Seabra Nunes (Universidade Nilton Lins, Manaus, AM, Brasil), Amanada Ellen de Morais (Universidade Federal do Amazonas, Manaus, AM, Brasil), Jéssica Alves Potulski (Universidade Federal do Amazonas, Manaus, AM, Brasil), Alessandra Encarnação de Morais (Universidade Federal do Amazonas, Manaus, AM, Brasil), Lucas de Morais Martins Pereira (Universidade Federal do Amazonas, Manaus, AM, Brasil), Rafael Assi Benvenutti (Universidade Federal do Amazonas, Manaus, AM, Brasil), Lorena Praia de Souza Bezerra (Universidade Federal do Amazonas, Manaus, AM, Brasil), Luma Ximenes de Oliveira (Universidade Federal do Amazonas, Manaus, AM, Brasil), Fernanda de Souza Henrique (Universidade Federal do Amazonas, Manaus, AM, Brasil), Laisa Ezaguy de Hollanda (Universidade Federal do Amazonas, Manaus, AM, Brasil), Sandra Lúcia Euzébio Ribeiro (Universidade Federal do Amazonas, Manaus, AM, Brasil), Rosana Barros Souza (Universidade Federal do Amazonas, Manaus, AM, Brasil)

\section{BACKGROUND}

The "PACE Prevenção de Doenças Reumáticas" is an extracurricular project in which medical students from Manaus have the opportunity to talk, teach, and help patients with rheumatic diseases, carry knowledge and solve patient's doubts about their disease and how to prevent them. To do this, a BINGO game was developed. This BINGO game created a chance to have a discussion with patients that we would otherwise not have. We were able to present information about health problems and solutions to ease these problems with the audience.

\section{MATERIALS AND METHODS}

The community activity was developed in one of Manaus' parks with the goal ofattending to the elderly population, although different age groups were present. The intervention took place through an interactive bingo game, in which, 60 cards were distributed with words that referred to topics of rheumatic diseases, like osteoporosis and osteoarthritis. The words were selected and the participants were encouraged to identify them in their cards while one of the students give an explanation on the wordin a 5 to 10 minute presentation with orientation about the disease's prevention and clarification of any doubts. Those who completed a horizontal or vertical line won a prize.

\section{RESULTS}

The evaluation of the results was made through feedback with the elderly at the end of the event. This approach aspired to a thematic and interactive discussion with the elderly about common rheumatologic diseases, such as low back pain, rheumatoid arthritis, gout, and osteoporosis. The interaction between lecturers and the target audience proved to be effective since most of the elderly were interested in learning more about the topic, always asking questions after the lectures on the subjects. Most of the participants recognized the extreme importance of the information exposed in the activity and they became aware that, in addition to hearing this knowledge, they should become disseminators of this information to those close to them.

\section{CONCLUSION}

Thus, we can highlight that by dispersing knowledge about rheumatologic diseases for the elderly in an interactive and dynamic way, we have a more effective and humanized health promotion. 